J. Product. \& Dev., 23(3): 755 - 788(2018)

\title{
EFFECT OF PLANTING DATE, IRRIGATION LEVEL AND FOLIAR SPRAYING WITH CALCIUM AND BORON TREATMENTS ON POTATO \\ 1. PLANT GROWTH , PLANT WATER RELATIONSHIP AND PLANT CHEMICAL CONSTITUENTS
}

\author{
Fawzy Y. O. Mansour* and Hanan M. Abu El-Fotoh** \\ * Hort. Research Institute, ARC., Giza, Egypt \\ ** Soil, Water and Environ., Research Institute, ARC, Giza, Egypt
}

\section{ABSTRACT}

A filed experiment was carried out during the two successive seasons of 2016/2017 and 2017/2018 at the Experimental Farm of ElGemmeiza, Agric Res. Station, A. R.C., Gharbya Governorate (Middle Delta, Egypt) to study the effect of planting date $\left(20^{\text {th }}\right.$ September (Sep.) and $10^{\text {th }}$ October (Oct.), irrigation water level at 50, 75 and $100 \%$ from the filed capacity $(F C)$ and two foliar spray treatments with calcium chloride (1\%) and boron ( 60 ppm) singly or in combinations, beside unsprayed treatment as well as their interactions on growth, plant water relationship and plant chemical composition of potato (Mondial cv.) under clay soil conditions using flood irrigation system. These treatments were arranged in a split split plot design with three replicates. Planting date was arranged in the main plots, irrigation water quantities were in the sub plots, while foliar spray treatments were randomly distributed in the sub sub plots.

The obtained results indicate that, the tertiary interactions of planting on $10^{\text {th }}$ Oct., irrigation at $100 \%$ of FC and spraying potato plants with calcium and boron in combination gave the highest values of plant height, both fresh and dry weight of shoot/ plant, total and free water \% as well as total chlorophyll $(a+b)$ in leaf tissues, $N, P, K, C a$, Boron and total carbohydrates contents in shoots in both seasons. While the tertiary interactions of planting on $20^{\text {th }}$ Sep., irrigation level at $50 \%$ from FC and unsprayed with calcium and boron gave the highest values of bound water \% and proline amino acid in leaf tissues in both seasons. 
Conclusively, under similar conditions it could be concluded that, the tertiary interaction of planting on $10^{\text {th }}$ Oct, irrigation at $100 \%$ $F C$ and sprayed plants with $\mathrm{Ca}+\mathrm{B}$ were the best interaction treatments for enhancing plant growth and chemical constituents in shoot of potato grown in clay soil under the same conditions.

Key words: Planting Date, Irrigation Level \& Foliar Spraying, Calcium, Boron, Potato, Plant Growth, Plant Water.

\section{INTRODUCTION}

Potato (Solanum tuberosum L.) belongs to Solanaceae family is one of the most important vegetable crops in the world and in terms of human consumption, it comes in the fourth grade after wheat, rice, and corn, it is rich in carbohydrates, nutrients and amino acids (Hassan 2003).

Planting date plays an important role in potato production as manipulation of light and temperature can be done to a certain extent by altering planting date. For best yields, potato crop needs long day conditions during growth and short day conditions during tuberization (Chadha, 2009). Optimum temperatures for foliage growth and net photosynthesis are $15-25^{\circ} \mathrm{C}$ and $20^{\circ} \mathrm{C}$ for tuberization. At temperature above $29^{\circ} \mathrm{C}$ tuberization is inhibited, foliage growth is promoted and net photosynthesis and assimilate partitioning to the tubers are reduced (Levy, 1992). There were a significant differences between planting date regarding plant growth of potato (Sandhu et al. 2014 , Thongam et al. 2017 and Dash et al. 2018).

Potato plant is sensitive to the changes in the soil moisture content .The decrease of water (water stress), leading to a significant reduction in tubers quantity and quality. The requirement for water irrigation of potato plants vary in different plant growth stages; tubers initiation and tubers bulking are the more sensitive stages in the plant growth life (Abdallah 1996).

Most studies found that irrigated potato plants with the highest levels caused significant increasing in plant growth ( El Saidi et al. 2010, Al-Janaby 2012, Abu Baker et al., 2014 and Dash et al., 2018) of potato. As for total chlorophyll (Abdel-Al 2001 and Bao-Zhong et al., 2003). Concerning plant water relationship in leaves (Abdel-Rheem, 2003,El-Ghamriny et al. 2005, Mahmoud 2006 and Khalel 2015) of potato. Regarding plant chemical 
constituents' (Anwar 2005, Abou El-Khair et al. 2011 of potato and Kamal, and El-Shazly 2013) on tomato.

Calcium is one of the essential plant nutrients and performs a significant role in plant membrane structure and function where it contributes to maintenance of cell membrane stability and wall structure (Marschner 1995). Also promotes root development and growth of the plant as it is involved in root elongation and cell division, Calcium therefore increases plant tissue resistance against biotic and abiotic stress (Ilyama et al. 1994).

Boron is second most widespread and economically important micronutrient which is essential for several growth related parameters. Its requirement is high after 45 days of crop emergence and remain high till crop maturity. It improves calcium absorption and stabilizes calcium in cell wall. Boron reduces the oxidation of phenols and prevent discolouration of tubers (Brown et al., 2002). Under drought condition the deficiency of boron is observed due to lower availability of (B) in sub-soils (Prasad, 2014). Its deficiency causes the formation of a bushy plant with droopy leaves.

Sprayed potato plants with $\mathrm{Ca}$ and/or $\mathrm{B}$ had affected on plant growth ( El-Mahdy, 2007, El- Dissoky and Abdel-Kadar 2013, Chowdhury 2017, Simango and Walls 2017 and Tantawy et al. 2017), total chlorophyll (Awad et al. 2010 and Singh et al. 2018 on potato) and (Kazemi 2013 of tomato) and plant chemical constituents ( El -Dissoky Abdel-Kadar 2013, Tantawy et al. 2017 and Seifu, and Deneke 2017) of potato.

Therefore, the present study was planned to evaluate the more appropriate planting date and suitable amount of irrigation water as well as calcium or/ and boron as foliar application on growth, plant water relationship and chemical composition of potato plants using flood irrigation system under clay soil conditions.

\section{MATERIALS AND METHODS}

A filed experiment was carried out in the successive winter seasons of 2016/2017 and 2017/2018 at the experimental Farm El- Gemmeiza, Agric Res. Station, ARC, Gharbiya Governorate (Middle Nile Delta, Egypt) to study the effect of planting date, irrigation water level and foliar sprays of $\mathrm{Ca}$ and/or $\mathrm{B}$ and their interactions on potato on growth, plant water relationship and plant chemical composition of potato (Mondial cv.) under 
furrow irrigation. The soil in the experimental site is clayey in texture with bulk density, field water capacity and available water values, in the $60 \mathrm{~cm}$ depth of the soil profile, comprised $1.25\left(\mathrm{gcm}^{-3}\right), 43.01$ and $17.92 \%$ by mass, respectively.

The mechanical and chemical analysis of the used soil are presented in Table (A). Particle size distribution was carried out using the method of Piper (1950). Calcium carbonate was determined using Collins calcimeter according to Wright (1939). Organic matter was assayed according to method of Walkley (1947). Total available nitrogen was determined using the microkjeldohl and Phosphorus was determined according to methods as described by Chapman and Pratt (1961). Potassium was determined using Flam photometeric method described Piper (1938). Available B was determined by Bingham (1982). $\mathrm{pH}$ value was measured in the soil past using Bechman $\mathrm{pH}$ meter.

Table (A): The mechanical and chemical analysis of the experimental soil

\begin{tabular}{|l|c|c|}
\hline Parameters & \multicolumn{2}{|c|}{ Values } \\
\hline 1. Mechanical analysis & First season & Second season \\
\hline Corse sand (\%) & 1.60 & 1.50 \\
\hline Fine sand (\%) & 12.91 & 14.4 \\
\hline Silt (\%) & 37.23 & 35.9 \\
\hline Clay (\%) & 42.79 & 43.20 \\
\hline CaCO $_{3}(\%)$ & 3.90 & 3.20 \\
\hline Organic matter (\%) & 1.57 & 1.80 \\
\hline Texture class & Silty clay loam & \\
\hline 2. Chemical analysis & & 33.0 \\
\hline Available nitrogen (ppm) & 8.0 & 8.8 \\
\hline Available phosphorus (ppm) & 420 & 440 \\
\hline Available potassium (ppm) & 0.10 & 0.12 \\
\hline Available boron (ppm) & 6 meq/l & \\
\hline Soluble calcium ( Ca $\left.{ }^{++}\right)$ & 8.0 & 8.0 \\
\hline $\begin{array}{l}\text { Soil reaction (pH) in 2.5 soil } \\
\text { suspension }\end{array}$ & & \\
\hline
\end{tabular}


The present experiment included 24 treatments, which were the combination of two planting date e.g. planting on $20^{\text {th }}$ Sept and $10^{\text {th }}$ Oct, three irrigation water level vis 50, 75 and $100 \% \mathrm{FC}$ and three foliar spray treatments i.e. $\mathrm{Ca}(1 \%, \mathrm{wt} / \mathrm{vol})$ as calcium chloride and/or boron $(60 \mathrm{ppm}$ as boric acid), besides the control (unsprayed treatment). The assessed treatments were arranged in a split - split plot design with three replicates. The planting dates were represented in the main plots, sub plots were assigned for irrigation levels and $\mathrm{Ca}$ and/or $\mathrm{B}$ foliar sprays and control treatments were randomly distributed in the sub - sub plots.

The experimental unit area was $14.7 \mathrm{~m}^{2}$ containing three ridges with $7 \mathrm{~m}$ length and $70 \mathrm{~cm}$ apart, and the potato seeds (Solanum tuberosum L. Mondial cv) were sown at $20 \mathrm{~cm}$ in between. One ridge was used to measure the morphological and physiological traits and the other two ridges were left for yield determinations. In addition, one ridge was left as buffer zone between each two experimental units to avoid lateral seepage of irrigation water. All the agronomic practices recommended for potato production in the area e.g. seed - bed preparation, N, P \& K fertilization, weed and pest control etc., were executed. Calcium chloride and boric acid were sprayed three times in two 2- week interval, and started 45 days after planting using a manual atomizer.

The irrigation water was added each three weeks intervals beginning at $10^{\text {th }}$ and $30^{\text {th }}$ October (20 days after planting) and ended $5^{\text {th }}$ and $25^{\text {th }}$ Jun. (15 days before harvesting) in the $1^{\text {st }}$ and $2^{\text {nd }}$ seasons, respectively. Under the adopted irrigation treatments, four irrigation events plus the planting one were applied throughout the entire growing season. To determine water quantity required under each adopted irrigation level, a soil sample (up to $60 \mathrm{~cm}$ depth) was taken before each irrigation from 100\% FC treatment, and soil moisture content $(\%, \mathrm{wt} / \mathrm{wt}$ basis) was calculated. The water quantity required to refill the $60 \mathrm{~cm}$ of soil profile to field capacity could be determined as follows:

Water required, $\mathrm{mm}=\mathrm{FC}-\mathrm{MC} \mathrm{x} \mathrm{Bd} \mathrm{x}$ soil layer depth $(600 \mathrm{~mm}) / 100$ Where: $\mathrm{FC}=$ Soil field capacity $\%$ by weight $(\mathrm{g}), \mathrm{MC}=$ Soil moisture content $(\%)$ by weight before irrigation $(\mathrm{g}), \mathrm{Bd}=$ Bulk density of $60 \mathrm{~cm}$ depth, $\mathrm{gcm}^{-3} \quad \ldots$ And $600=$ depth of root zone, $\mathrm{mm}$. 
Then, multiplying water quantity required for $100 \%$ FC level by 0.75 and 0.50 to attain water quantities required for 75 and $50 \% \mathrm{FC}$, respectively.

On applying the pre-determined water quantity, a plastic tube (spile) with internal diameter of 3 inches was used to apply and calculate the water quantity according to Michael (1987) as follows:

Water quantity, $\mathrm{cm}^{3} \mathrm{sec}^{-1}=0.61 \times \mathrm{A} \sqrt{ } 2 \times 981 \times \mathrm{h}$

Where: $\mathrm{A}=$ sectional tube area, $\mathrm{cm}^{2}$ and $\mathrm{h}=$ Effective water head over the tube, $\mathrm{cm}$.

\section{Data recorded}

Growth traits and shoot chemical analysis were determined at 90 days after planting, while yield determinations were recorded at harvesting on $20^{\text {th }}$ Jun and $10^{\text {th }} \mathrm{Feb}$. in the $1^{\text {st }}$ and the $2^{\text {nd }}$ seasons, respectively. Five plants from each experimental plot were used to measure the growth traits and plant chemical analyses. The recorded data were:

1. Plant growth: It was recorded as plant height, number of leaves/ plant, both fresh and dry weight of shoot / plant (g).

2. Plant water relations: It was recorded in the fourth upper leaf of potato plant as: total, free and bound water as well as cell sap and osmotic pressure according to the method described by Gosev (1960).

3. Proline amino acid content: It was determined in dry leaves according to the method described by Bates (1973).

4. Total chlorophyll in leaf tissues (chlorophyll a + chlorophyll b) was extracted and determined according to Moran (1982).

5. Percentages of $N, P$ and $K$ in shoots: Total Nitrogen, phosphorus and potassium percentages were determined in dried and wet digested shoots according to the methods described by A.O.A.C. (1990), also boron was determined in shoots calorimetrically using azomethine $-\mathrm{H}$ method according to Bingham (1982) and soluble calcium was determined by the method of Cottenie et al. (1982), total Hydrolysable carbohydrates (T.H.C.) were determined in shoots using picric acid method according to Thomes and Dutcher (1924).

\section{Statistical Analysis:}

Collected data were subjected to statistical analysis of variance according to Snedecor and Cochran (1980), and means separation was done using L.S.D. at $5 \%$ level of probability. 


\section{RESULTS AND DISCUSSION}

\section{Soil chemical constituents after planting}

Data in Table 1 show the effect of the interactions among planting date, irrigation levels and foliar spray treatments with calcium and boron on soil chemical constituents after potato plants (average the two seasons).

Both planting dates, irrigation at $100 \%$ from FC and spraying plants with $\mathrm{Ca}$ and $\mathrm{B}$ gave the highest values of available $\mathrm{N}$ in soil ( $52.30 \mathrm{ppm}$ ) average both seasons), available $\mathrm{P}$ was the highest $(12.40 \mathrm{ppm})$ with the interaction between planting on $10^{\text {th }}$ October, irrigation with $100 \%$ from FC and spraying plants with $\mathrm{B}$ at $60 \mathrm{ppm}$, while the highest available $\mathrm{K}$ in the soil (587.33 $\mathrm{ppm}$ ) was recorded with the interaction among planting on $10^{\text {th }}$ Oct., irrigation at $75 \%$ from $\mathrm{FC}$ and spraying plants with $\mathrm{Ca}$ and $\mathrm{B}$. on the other hand, the lowest values of $\mathrm{pH}(7.90)$ and $\mathrm{EC}(0.24)$ were recorded with the interactions among planting on $20^{\text {th }}$ Sep. and irrigation plants with $50 \%$ from FC and unsprayed plants.

\section{Plant Growth}

\subsection{Effect of planting date}

Data in Table 2 show that, there were significant differences between the two planting date regarding plant growth of potato in both seasons, except number of leaves / plant in the $2^{\text {nd }}$ season. Planting potato on $10^{\text {th }}$ Oct. gave the tallest plants, highest values of both fresh and dry weight of shoots/ plant than planting on $20^{\text {th }}$ Sep. in both seasons. The increases in dry weight of shoots/ plant were about 14.51 and $12.41 \%$ for Planting potato on $10^{\text {th }}$ Oct. over than planting on $20^{\text {th }}$ Sep. in the $1^{\text {st }}$ and the $2^{\text {nd }}$ seasons, respectively.

The higher plant growth in planting date on $10^{\text {th }}$ Oct. as compared to the planting date on $20^{\text {th }}$ Sep. could be attributed to favorable climatic conditions in general and temperature in particular (Thongam et al. 2017). These results are harmony with those reported by Sandhu et al. (2014) and Thongam et al. (2017).

\subsection{Effect of water irrigation levels}

The obtained results in Table 2 show also that irrigation level had a significant effect on plant height, number of leaves/ plant, both fresh and dry weight of shoots/ plant in both seasons. Potato plants which irrigated with 100 $\%$ from FC gave the highest values of different plant growth characters in both 
seasons. While the lowest values were recorded with $50 \%$ from FC. On the other side, irrigation at $75 \%$ from FC recorded the moderate values in both seasons.

The increases in shoot dry weight were about 23.48 and $20.04 \%$ for irrigation treatment at $100 \%$ from FC than plants which irrigated with $50 \%$ from $\mathrm{FC}$ in the $1^{\text {st }}$ and the $2^{\text {nd }}$ seasons, respectively.

The improvement of vegetative growth with increasing irrigation level may be due to the proper balance of moisture in plant, which creates favorable conditions for nutrients uptake, photosynthesis and metabolites translocation, which ultimately accelerated the rate of vegetative growth (Ezzo et al., 2010). Moreover the reduction effect of the lowest level of irrigation water (50\% of FC ) may be related to the negative effects of water stress on the activities of many enzymes leading to decrease in plant growth and dry matter accumulation (Hamlyn, 1986). On the other hand, Marschner (1995) reported that, under sufficient water conditions, there were decrease in Abscisic acid (ABA) and increase in Cytokinins (CYT), Gibberllic acid (GA) and Indole butyric acid (IAA) which reflected in good growth and dry matter content.

The obtained results are in good line with those reported by Shiri-e- et al. (2009), El Saidi et al. (2010), Al-Janaby (2012), ABuBAker, et al. (2014) and Dash et al. (2018)on potato. They reported that increasing irrigation water quantity or soil moisture content up to the maximum level significantly increased vegetative growth such as plant height, number of leaves/ plant both fresh and dry weight of shoots/ plant.

\subsection{Effect of foliar spray treatment}

Spraying potato plants with $\mathrm{Ca}$ and /or B had significant effect on all plant growth parameters than unsprayed plants in both seasons (Table 2). Furthermore combined application of $\mathrm{Ca}$ and boron improved the growth trails of potato plants more than which recorded by single application of $\mathrm{Ca}$ or boron.

In this regard, the plants which sprayed with both $\mathrm{Ca}$ and $\mathrm{B}$ gave the higher values of plant height, number of leaves / plant, both fresh and dry weight of potato plant than that of plants which sprayed with calcium or boron singly in both seasons. 
The increases in shoot dry weight were about 18.57 and $16.84 \%$ for sprayed plants with calcium and boron than unsprayed plants in the $1^{\text {st }}$ and the $2^{\text {nd }}$ seasons, respectively.

Calcium sensing proteins are involved in many cellular processes like cytoplasmic streaming, organelles and vesicles transport, microtubules dynamics, cell division, chromosome segregation, cell elongation, tip growth and morphogenesis (Reddy, 2001). Also, Jafari et al. (2013) showed that spraying of boron significantly improved growth parameters of potato plants (plant height, leaves per plant and shoot weight) as compared with control,

These results confirmed by the findings of El-Mahdy, (2007), ElDissoky and Abdel-Kadar (2013), Chowdhury (2017), Simango and Walls (2017) and Tantawy et al. (2017) all on potato, they reported that spraying plants with calcium or boron singly or in combination gave the best plant growth then unsprayed plants.

\subsection{Effect of the interaction between planting date and irrigation level}

It can be seen from the data presented in Table 3 that the interaction between planting date and irrigation water level had significant effect on all potato growth than the other interaction treatments in both seasons. The interaction between planting potato on $10^{\text {th }}$ Oct. and irrigation water at $100 \%$ from FC gave the highest values of plant height, number of leaves/ plant and both fresh and dry weight of shoots/ plant in both seasons.

These increases in shoot dry weight were about 38.37 and $32.11 \%$ for the interaction between planting potato on $10^{\text {th }}$ Oct. and irrigation water at $100 \%$ from FC than the interaction between planting potato on $20^{\text {th }} \mathrm{Sep}$. and irrigation water at $50 \%$ from FC in the $1^{\text {st }}$ and the $2^{\text {nd }}$ seasons, respectively.

\subsection{Effect of the interaction between planting date and foliar spraying treatments}

The interaction between planting date and foliar spraying treatments reflected in a significant effect on all plant growth characters of potato in both seasons (Table 3 ). Planting potato on $10^{\text {th }}$ Oct. and spraying plants with calcium and boron recorded the highest values of plant height, number of leaves/ plant and both fresh and dry weight of shoots/ plant.

These increases in shoots dry weight were about 36.32 and $32.80 \%$ for the interaction between planting potato on $10^{\text {th }}$ Oct. and spraying plants with both 
calcium and boron than that plants which planted on $20^{\text {th }}$ Sep. only in the $1^{\text {st }}$ and the $2^{\text {nd }}$ seasons, respectively.

\subsection{Effect of interaction between irrigation levels and foliar spray treatments}

The interaction between irrigation level and foliar spray treatments had a significant effect on all plant growth characters of potato plants than the other interaction treatments in both seasons (Table 4). Irrigation the plants with 100 $\%$ from FC and spraying plants with both calcium and boron recorded the highest values of plant height, number of leaves/ plant, both fresh and dry weight of shoots/ plant in both seasons, while the lowest values in this respect was recorded with the interaction between the plants which irrigated with $50 \%$ from FC in both seasons. The increases in shoots dry weight of sweet potato plant were about 45.33 and $40.74 \%$ for the interaction between irrigation plants with $100 \%$ from FC and spraying plants of calcium and boron over that plants which irrigated with $50 \%$ from FC in the $1^{\text {st }}$ and the $2^{\text {nd }}$ seasons, respectively.

\subsection{Effect of tertiary interaction of planting date, irrigation level and some foliar spray treatments}

The interaction of planting date, irrigation level and foliar spray treatments had a significant effect on some plant growth characters parameters of potato in both seasons (Table 5). The tertiary interaction of planting on $10^{\text {th }}$ Oct. , irrigation with $100 \%$ from FC and spraying plants with calcium and boron recorded the highest values of plant height, number of leaves/ plant and both fresh and dry weight of shoots/ plant in both seasons. The lowest values in this respect was recorded with the interaction between planting on $20^{\text {th }}$ Sep., irrigation with $50 \%$ from FC and unsprayed plants in both seasons. The increases in shoot dry weight of potato plant were about 71.60 and $63.93 \%$ for the tertiary interaction of planting on $10^{\text {th }}$ Oct., irrigation with $100 \%$ from FC and sprayed with calcium plus boron over the interaction among planting on $20^{\text {th }}$ Sep., irrigation with $50 \%$ from $\mathrm{FC}$ in the $1^{\text {st }}$ and the $2^{\text {nd }}$ seasons, respectively.

\section{Plant water relations, proline amino acid and leaf pigments 3.1. Effect of planting date}

Data in Table 6 show that planting date had a significant effect on plant water relation, proline amino acid in leaves and total chlorophyll in both seasons. 
Planting potato on $10^{\text {th }}$ Oct. gave the highest values of total and free water $\%$, as well as total chlorophyll in the leaf tissues, while planting on $20^{\text {th }}$ Sep. gave the highest values of bound water \% and proline amino acid in leaf tissues in both seasons.

\subsection{Effect of irrigation water level}

Irrigation water levels had a significant effect on total, free and bound water $\%$ in leaf tissues as well as proline amino acid and total chlorophyll in leaf tissues in both seasons ( Table 6).

Total and free water as well as total chlorophyll in leaf tissues were the highest significantly increased by increasing irrigation water levels up to 100 $\%$ from FC in both seasons. While, bound water (\%) and proline amino acid in leaf tissues were the superior with the lowest level of irrigation water in both seasons.

From the previously mentioned results, it could be suggested that, the increment in water supply would increase the soil moisture content, which in turn would probably led to increase the available water in the soil. Which resulted to increase water absorption and then increased both total and free water in leaf tissues. As free water content increase, bound water content should be decrease. Moreover, the increase in the bound water and decrease in free water under water stress was mainly due to the increases in cell sap concentration and its osmotic pressure resulted from the conversion of starch into soluble carbohydrates (Lancher, 1993).

These results are in accordance with those reported by Abdel-Al (2001), Bao-Zhong et. al. (2003) and Youssef (2007) as for total chlorophyll and Abdel-Rheem (2003), El-Ghamriny et al. (2005), Mahmoud (2006) and Khalel (2015) for plant water relationship and proline amino acid in potato leaves tissues .

\subsection{Effect of foliar spray treatments}

Spraying potato plants with calcium and boron had significant effect on total, free water \% and total chlorophyll in leaf tissues than unsprayed plants, while unsprayed plants significantly increased bound water $\%$ and proline amino acid in leaf tissues in both seasons ( Table 6).

Similar observations also recorded by Awad et al. (2010) and Singh et al. (2018) on potato) and Kazemi (2013) on tomato. 


\subsection{Effect of interaction between planting date and irrigation level}

Data presented in Table 7 show that, the interaction between planting date and irrigation level had a significant effect on studied plant water relationships, proline amino acid and total chlorophyll in leaves of potato in both seasons. The interaction between planting on $10^{\text {th }}$ Oct. and irrigation with $100 \%$ from FC gave the higher values of total, free water $\%$ and total chlorophyll in leaves tissues, while the interaction between planting on $20^{\text {th }}$ Sep. and irrigation with $50 \%$ from FC recorded the higher values of bound water $\%$ and proline amino acid in both seasons.

\subsection{Effect of interaction between planting date and foliar spray treatments}

The interaction between planting on $10^{\text {th }}$ Oct. and foliar spray with calcium and boron in the combination significantly increased total, free water $\%$ and total chlorophyll in leaf tissues in both seasons, while the interaction between planting on $20^{\text {th }}$ Sep. and unsprayed plants significantly increased bound water $\%$ and proline amino acid in leaf tissues in both seasons (Table 7).

\subsection{Effect of interaction between irrigation level and foliar spray treatments}

The interaction between irrigation levels and some foliar spray treatments had significant effect on all plant water relationship, proline amino acid and total chlorophyll in leaf tissues in both seasons (Table 8). The highest values of total, free water $\%$ and total chlorophyll were obtained with the interaction between irrigation potato plants with $100 \%$ from FC and sprayed plants with the combination of calcium and boron, while the bound water $\%$ and proline amino acid were highest in plants which irrigated with $50 \%$ from FC and unsprayed with calcium or boron in both seasons.

\subsection{Effect of tertiary interaction among planting date, irrigation level and foliar spray treatments}

Total, free water $\%$ and total chlorophyll in leaf tissues significantly increased with the tertiary interaction among planting on $10^{\text {th }}$ Oct., irrigation with $100 \%$ from FC and sprayed potato plants with calcium and boron in combination in both seasons. While the tertiary interaction among planting on $20^{\text {th }} \mathrm{Sep}$., irrigation with $50 \%$ from FC and unsprayed plants with calcium or boron significantly increased bound water $\%$ and proline amino acid in tissues in both seasons (Table 9). 


\section{Nitrogen, $P, K, C a, B$ and total carbohydrates in shoots 4.1. Effect of planting date}

Planting date had a significant effect on $\mathrm{Ca}, \mathrm{B}$ and total carbohydrates in both seasons and $\mathrm{P}$ in the $1^{\text {st }}$ and $\mathrm{K}$ content in shoots in the $2^{\text {nd }}$ season, but it had no significant effect in $\mathrm{N}$ content in shoot in both seasons ( Table 10).

Planting potato on $10^{\text {th }}$ Oct. gave the highest values of $\mathrm{Ca}, \mathrm{B}$ and total carbohydrates contents in their shoots in both seasons, $\mathrm{P}$ content in the $1^{\text {st }}$ and $\mathrm{K}$ content in shoots in the $2^{\text {nd }}$ season.

These results are agree with those reported with Sandhu et al. (2014) and Dash et al. (2018).

\subsection{Effect of irrigation water level}

Calcium, Boron and total carbohydrates contents in potato shoots in both seasons, $\mathrm{N}$ contents in the $2^{\text {nd }}$ season and $\mathrm{P}$ content in the $1^{\text {st }}$ season significantly increased by increasing irrigation water levels up to the highest levels $100 \%$ form FC, while irrigation level had no effect on K content in shoots in both seasons. (Table 10).

Increasing the quantity of water applied to the soil increased the moisture content that make minerals more available to the plant. The increase in vegetative growth of potato plant by increasing irrigation water quantity might be due to that irrigation at $100 \%$ from FC resulted in lower stomata resistance, and hence higher conductance and photosynthetic activity. On the other hand, unfavorable effect of drought on dry matter production might be due to the reduction in uptake of nutritional elements that cause a disturbance in the physiological processes needed for plant growth (Slatyer, 1969) and or to the reduction in leaf area and photosynthetic rate (Fisher and Hagan, 1965) and/or to that low water level also caused reduction in $\mathrm{CO}_{2}$ assimilation due to stomata close (Hsiao and Acevedo, 1974), and/or to that the photosynthetic efficiency began to decrease with a slight deficit in the soil moisture content due to the decrease in the mesophyll photosynthetic activity at high xylem water potential (Gawish, 1992).

These results are in lines with those reported by Nahar and Gretzmacher (2002) on tomato, Anwar (2005), Abou El-Khair et al. (2011) on potato and Kamal, and El-Shazly (2013) on tomato. 


\subsection{Effect of foliar spray treatments}

Spraying potato plants with $\mathrm{Ca}$ and $\mathrm{B}$ singly or in combination had significant effect on all minerals contents and total carbohydrates in shoot than unsprayed plants in both seasons ( Table 10).

$\mathrm{N}, \mathrm{P}, \mathrm{K}, \mathrm{Ca}$ and $\mathrm{B}$ were highest in plants which sprayed with $\mathrm{Ca}$ and $\mathrm{B}$ in combination in both seasons, and total carbohydrates were highest in plants which sprayed with $B$ in both seasons.

The enhancement in mineral uptake by foliar application of boron may be a result of its roles in stimulating plant biological activities such as photosynthesis, enzyme activities, nutrient uptake and rate of translocation of photoasssimilates. Moreover, the stimulating effect of B on plant growth may be due to its role in cell development and the production of IAA which is essential for the elongation of plants (Follett et al., 1981).

Canda (2002) explained the higher $\mathrm{P}$ content due to the influence of boron on membrane-bound ATPase activity in addition, heavy K-demanded crops in the bulking stage of production will require 60-80 ppm boron levels in the tissue in order to take up their demand of potassium. The increment in boron content is expected due to the application of this nutrient.. The higher $\mathrm{K}$ content was explained by Mengel and Kirkby (1978) based on the synergism relationship between $\mathrm{K}$ and $\mathrm{B}$ at sugar and carbohydrate transport.

These results are in harmony with those reported with El -Dissoky and Abdel -Kadar (2013), Tantawy et al. (2017) and Seifu, and Deneke (2017) on potato.

\subsection{Effect of interaction between planting date and irrigation level}

Data presented in Table 11 showed that, the interaction between planting dates and irrigation levels had significant effect in all mineral and total carbohydrates contents in shoots both seasons, except $\mathrm{N}$ and $\mathrm{K}$ in the $2^{\text {nd }}$ and $\mathrm{P}$ in $1^{\text {st }}$ season.

The interaction between planting on $10^{\text {th }}$ Oct. and irrigation levels with $75 \%$ from FC recorded the highest values of $\mathrm{N}$ and $\mathrm{K}$ contents in the $2^{\text {nd }}$ season, $\mathrm{P}$ in the $1^{\text {st }}$ season and total carbohydrates in both seasons, Ca and $\mathrm{B}$ content were highest with the interaction between planting on $10^{\text {th }}$ Oct. and irrigation levels with $100 \%$ from FC in both seasons. 


\subsection{Effect of interaction between planting date and foliar spray treatments}

The interaction between planting on $10^{\text {th }}$ Oct. and foliar spray with $\mathrm{Ca}$ and $\mathrm{B}$ in combination reflected a significant effect on of N,P , K, Ca and B contents in shoots in the two seasons, total carbohydrates was highest with the same date and sprayed plants with boron in both seasons (Table 11).

\subsection{Effect of interaction between irrigation level and foliar spray treatments}

Irrigation potato plants with $100 \%$ from FC and sprayed their plants with $\mathrm{Ca}$ and $\mathrm{B}$ in combination had a significant increase in $\mathrm{N}, \mathrm{P}, \mathrm{K}, \mathrm{Ca}$ and $\mathrm{B}$ contents in shoots in both seasons. Total carbohydrates were highest with the same levels of irrigation and spraying plants with B in both seasons. On the other hand, the lowest values of above mentioned traits were recorded with the plants which irrigated with $50 \%$ FC and unsprayed plants with $\mathrm{Ca}$ or boron in both seasons (Table 12).

\subsection{Effect of tertiary interaction of planting date, irrigation level and foliar spray treatments}

The tertiary interaction of planting date, irrigation level and foliar spray treatments had a significant effect in all mineral contents and total carbohydrates in shoots in both seasons ( Table 13). The interaction between planting on $10^{\text {th }}$ Oct., irrigation levels at $75 \% \mathrm{FC}$ and spraying plants with $\mathrm{Ca}$ and $\mathrm{B}$ gave the highest values of $\mathrm{N}$ and $\mathrm{K}$ contents, $\mathrm{P}$ content was highest with the interaction among planting in the same date, irrigation level at 50 $\%$ from $\mathrm{FC}$ and spraying plants with $\mathrm{Ca}$ and $\mathrm{B}$ in combination. Calcium, $\mathrm{B}$ and total carbohydrates were highest with the interaction of planting on $10^{\text {th }}$ Oct. , irrigation plants with $100 \%$ from FC and spraying plants with $\mathrm{Ca}$ and $\mathrm{B}$ in combination. The interaction among planting on $10^{\text {th }}$ Oct., irrigation plants with $100 \%$ from FC and spraying plants with B gave the highest total carbohydrates in both seasons.

Conclusively, it could be concluded that, the interaction between planting on $10^{\text {th }}$ Oct. irrigation level at $100 \%$ form FC and spraying plants with Ca and $\mathrm{B}$ in combination were the best interaction treatments for enhancing plant growth and chemical constituents of potato under clay soil. 


\section{REFERENCES}

A.O.A.C.(1990). Association of Official Agricultural Chemists. Official Methods of Analysis. 10 ${ }^{\text {th }}$. Ed. A.O.A.C., wash., D.c

Abdallah, S. A. M. (1996). Studies on the Application of Antitranspirant and Water Regimes on Potatoes Grown in Calcareous Soils. M.Sc. thesis, Fac.Agric., Alex. Univ., Egypt.

Abdel-Al, A.M.H. (2001). Effect of irrigation with saline water on potato plants. M.Sc. Thesis, Fac. Agric. Cairo Univ., Cairo, Egypt.

Abdel-Rheem, H.A. 2003. Effect of water stress and potassium fertilization on yield quantity and quality of potato. Ph.D. Thesis, Fac. Agric., Minia Univ., Egypt.

Abou El-Khair, E.E. , Dalia, A.S.Nawar and H. E.M. Ismail (2011). Effect of irrigation water quantity and farmyard manure on potato plant grown in sandy soil . Egypt J. Agric. Res., 89(1): 317:334.

ABuBAker, B. M. A. Y. ShuAng-En, S. GuAng-Cheng,M. AlhAdi and A. El Siddig (2014). Effect of irrigation levels on the growth, yield and quality of potato. Bulgarian J. Agric. Sci., 20 (No 2) , 303-309.

Al.Janaby M.A.A.F. (2012). Effect of drip irrigation, organic manure and mulching on growth and yield of potato.(Solanum tuberosum L.). Ph D. Thesis. Fac. Agric. Univ. Baghdad. Pp 133.

Anwar, R.S. (2005). Response of potato crop to biofertilizers, irrigation and antitranspiration under sandy soil conditions. Ph.D. Thesis, Fac. Agric., Zagazig Univ., Egypt.

Awad, El. M.M.; M.S. Emam and Z. S. El. Shall (2010). The influence of foliar spraying with nutrints on growth, yield and storability of potato tubers. J. Plant Prod., Mansoura Univ., 1 (10): 1313-1325

Bao-Zhong Y., M.Soich and Y.Kang (2003). Effect of different irrigation regimes on the growth and yield of drip- irrigation potato. Agric. Water Managem., 63 : 153-167.

Bates, L. S. (1973). Rapid determination of proline for water stress studies. Plant and Soil, 39 : 205-207.

Bingham, F.T. (1982). Boron in Al. Page R.H. Miller and D.R. Keeny (eds). Methods of soil analysis, part 2, Agron. Monogr. G. Am. Soc. Agron., Madison, Wip.431-446. 
Brown, P.H., N. Bellaloui, M.A. Wimmer, E.S. Bassil, J. Ruiz, H. Hu and V. Römheld (2002). Boron In Plant Biology, Wiley's Journal Recommendation service. Vol.4 Issue 2, 205-223

Canada, A.L. (2002). "Fact Sheet No. 90": Boron as a Plant Nutrient. A \& L Canada Laboratories, 2136 Jetstream Rd., London, ON N5V 3P5, 519457-2575.

Chadha K.L. (2009). Handbook of Horticulture, ICAR, New Delhi,

Chapman, H.D. and P.F. Pratt (1961). Method of analysis for soils, plant and water Univ. Cal . Dir. Agric. Sci., USA, Pp. 150-152.

Chowdhury R.S. (2017). Effect of calcium, magnesium, sulphur, zinc and boron on growth and yield of potato (cv. Kufri Jyoti). M.Sc thesis, Fac. Hort. Uttar Banga Krishi Viswavidyalaya.

Cottenie, A., M. Verso, L. Kiekens, G. Velghe and R.Gamerlynck (1982). Chemical analysis of plant and soils. Lab of Analytical Agronomy state University, Chent-Belgium.

Dash S.N., Y. Pushpavathi and S. Behera (2018). Effect of Irrigation and Mulching on Growth, Yield and Water Use Efficiency of Potato. Int. J. Curr. Microbiol. App. Sci., (2018) 7(2): 2582-2587

El-Dissoky R.A. and A.E.S. Abdel-Kadar (2013). Effect of Boron as a Foliar Application on Some Potatoes Cultivars Under Egyptian Alluvial Soil Conditions. Res. J. Agric. Bio. Sci., 9(5): 232-240.

El-Ghamriny, E.A., A. Bardisi, A.N. Fayad and R.S. Anwar. 2005. Growth, plant water relations and chemical constituents of potato plants as affected by water quantity and some antitranspirants under sandy soil conditions. Zagazig J. Agric. Res., 32 (3):739-766.

El-Mahdy, R.E. (2007). Effect of heavy nitrogen application on pepper plant (Capsicum аппиит). M. Sci. Thesis Fac. Agric. Mansoura Univ., Egypt.

El Saidi, M.T., O.M. Kassab, E.M. Okasha and A.R.E. Abdelghany (2010). Effect of Drip Irrigation Systems, Water Regimes and Irrigation Frequency on Growth and Quality of Potato under Organic Agriculture in Sandy Soils. Aust. J. Basic Appl. Sci., 4(9): 4131-4141.

Ezzo, M.I.; A. A. Glala; A. M. H. Habib and A. A. Helaly (2010). Response of sweet pepper grown in sandy and clay soil lysimeters to water regimes. American-Eurasian J. Agric. and Environ. Sci., 8 (1):18-26. 
Fisher, R.A. and R.H. Hagan. 1965. Plant water relations, irrigation regimes management and crop yield. Exp. Agric., (1): 411-418.

Follett R.H.; K.S. Murphy and R.L. Donahue (1981). "Fertilizers and Soil Amendments". Prentice- Hall, New Jersey.

Gawish, Ragaa A.R. 1992. Effect of antitranspirants application on snap beans (Phaseolus vulgaris, L.) grown under different irrigation regimes. I. Growth, transpiration rate and leaf content of water, NPK and total carbohydrates. Minufiya J. Agric. Res., 17 (3): 1285-1308.

Gosev, N. A. (1960). Some methods in studying plant water relations. Leningrad Acad. of Science, U.S.S.R. (C.F. Hussein, M.H., Ph.D. Thesis, Fac. Agric., Ain Shams Univ., Cairo, Egypt, 1973).

Hamlyn, G. J. (1986). Drought and drought tolerance in plants and microclimate. Cambridge Univ. Press, Cambridge, London, New York, New Rochelle, Melbourne, Sydney, pp. 212-237

Hassan A.A. (2003). Potato. Dar-AL-Arabiya Publication.Cairo. Egypt. Pp. 198.

Hsiao, T.C. and E. Acevedo. 1974. Plant response to water deficits, water use efficiency and drought resistance. Agric. Meteorology, 14: 59-84.

Iiyama K, Lam TBT, Stone BA. 1994. Covalent cross-links in the cell wall. Plant Physiology, 104: 315-320.

Jafari, J. S., A. H. Shiranirad , J. Daneshian and A. Rokhzadi (2013). Effects of nitrogen application and spraying of boron and manganese on growth traits of two potato cultivars. International Journal of Biosciences, 3 (9): 298-303.

Kamal, A. M. and M. M. El-Shazly (2013). Maximizing the productivity and water use efficiency of tomato plants (Lycopersicon esculentum Mill.) cultivated in the new reclaimed lands using different irrigation water quantities and some water saving substances. J. Plant Production, Mansoura Univ., 4 (9): 1399 - 1416.

Kazemi M. (2013). Vegetative and reproductive growth of tomato plants affected by calcium and humic acid. Environment, Pharmacology, 2: 24-29.

Khalel A.S. (2015). Effect of drip irrigation intervals and some antitranspirants on the water status, growth and yield of potato (Solanum tuberosum L.) . J. Agric. Sci. Techn., (5): 15-23. 
Lancher, L. 1993. Physiological Plant Ecology. Ecophysiology and stress physiology of functional groups. Third edition springier press. Berlin, New York, London, Paris, Tokyo.

Levy D (1992). Potato in hot climates-could we do more. Proceeding Of Advanced Potato Production In The Hot Climates Symposium, Israel. pp: 3-7.

Mahmoud, M.M.S. 2006. The response of potato (Solanum tuberosum, L.) to water regimes and irrigation systems. Ph.D. Thesis, Fac. Agric., Minufiya Univ., Egypt.

Marschner H. (1995). Mineral Nutrition Of Higher Plants. 2nd ed. Academic Press London 285-299.

Mengel, K. and E.A. Kirkby, 1978. "Principles of Plant Nutrition", International Potash Institute, Bern, Switzerland.

Michael, A.M. (1978). Irrigation: Theory and Practices. Vikas Publishing House, Delhi.

Moran, R. (1982). Formula for determination of chlorophylls pigments extracted with NN. dimethyl form amide. Plant Physiology, 69:13761381.

Nahar, K. and R. Gretzmacher (2002). Effect of water stress on nutrient uptake, yield and quality of tomato (Lycopersicon esculentum Mill.) under subtropical conditions. Die Bodenkultur, 53 (1): 45- 51.

Piper, C.S. (1938). The occurrence of reclamation Disease in cereals in south Australia, Australia Council Sci. ind. Research Pamphlet, No.78:24-28

Piper, C.S. (1950). Soil and plant analysis Inter.Sci. Publishers, Inc., New York. Inter Sci. Publishers, inc., New York.

Prasad, R., Kumar, D, Shivay, YS and Rana, DS 2014. Boron in Indian agriculture - a review. Indian J. Agron., 59(4): 511-517.

Reddy, A. S. (2001). Calcium: silver bullet in signaling. Plant Sci., 160(3): 381404.

Sandhu A.S., S.P. Sharma , R.D. Bhutani and S.C. Khurana (2014). Effects of planting date and fertilizer dose on plant growth attributes and nutrient uptake of potato (Solanum tuberosum L.). Inter. J. Agric. Sci., 4 (5): 196202. 
Seifu, Y.W. and S. Deneke (2017). Effect of Calcium Chloride and Calcium Nitrate on Potato (Solanum tuberosum L.) Growth and Yield. J. Hortic ., 4: 207.

Shiri-e- J. M., A. Tobeh, S. Hokmalipour, Sh. Jamaati-e-Somarin, A. Abbasi and K. Shahbazi, (2009). Potato (Solanum tuberosum L.) response to drip irrigation regimes and plant arrangements during growth periods. Asian J. Plant Sci., 8: 390-399.

Simango. K., and J.E.V. Walls 2017. Effects of Different Soil Treatments on the Development of Spongospora subterranea f. sp. subterranea in Potato Roots and Tubers in the Greenhouse. European Association for Potato Research, 60:47-60

Singh S.K., M. Sharma , K.R. Reddy and T. Venkatesh (2018). Integrated application of boron and sulphur to improve quality and economic yield in potato. J. Environ. Bio., (39): 204-210.

Slatyer, R.O. 1969. Physiological significance of internal water relations to crop yield. In Eastin, J.D., F.A. Hoskins, and C.H. von Bovel (Eds.). Physiological aspects of crop yield. Pp. 53-88. Soc. Agron. and Crop Sci., Madison, Wisconsin.

Snedecor, G.W. and W.G. Cochran. (1980). Statistical Methods. $7^{\text {th }}$ ed., Iowa State Univ., Press, Ames., Iowa, U.S.A.

Tantawy, A. S., Y.A. Salama, S. A. Saleh and A. A. Ghoname (2017). Enhancing yield and quality of two potato cultivars by using boron foliar Application. Middle East J. Appl. Sci., 7 (3): 510-518.

Thomes, M. and R. A. Dutcher (1924). The calorimetric determination of $\mathrm{CHO}$ in plants by the picric acid reduction method. J. Amer. Chem. Soc., 46:7-12.

Thongam, B., A.S. Kadam, A.A. Singh and Y. H. Singh. (2017). Influence of planting dates on growth and yield of potato (Solanum tuberosum L.). Journal of Pharmacognosy and Phytochemistry , 6(6): 1243-1246

Walkley, A. (1947). A critical examination of a rapid method for determined organic carbon in soils. Effect of variation indigestion conditions and in organic soil constituents. Soil Sci., 63:246-251.

Wright, C.H. (1939). Soil Analysis. Thom as murby and Co., London. 
Youssef, M.E.A. (2007). Effect of some agricultural treatments on the growth, productivity, quality and storageability of potato. Ph.D. Thesis, Fac. Agric., Zagazig Univ., Egypt.

\section{تأثير ميعاد الزراعة ، مستويات الرى ومعاملات الرش الورقى الرئ

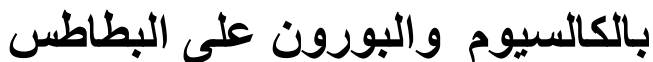 1- نمو النبات ، العلاقات المائيه فى النبات ، المكونات الكيميائيه للنبات}

$$
\begin{aligned}
& \text { فوزى يحيى عمر منصور - حنان محمد أبو الفتوح }
\end{aligned}
$$

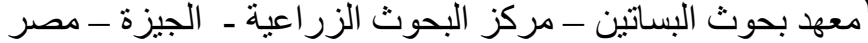

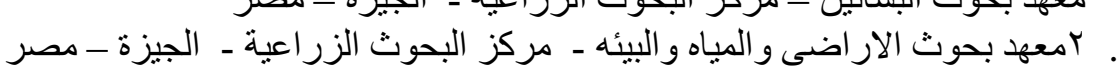

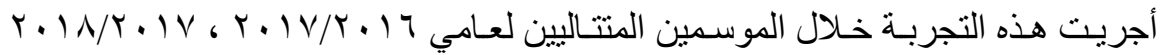

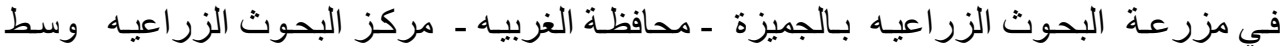

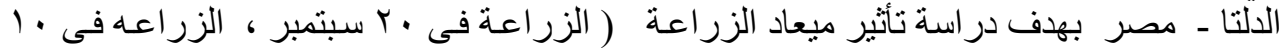

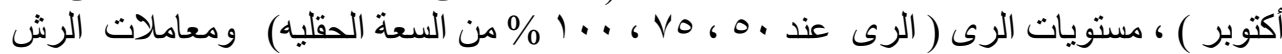

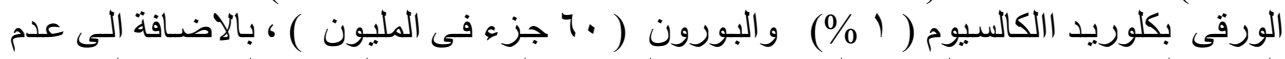

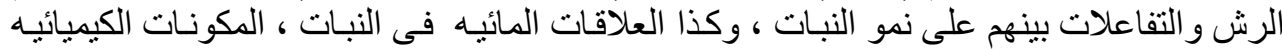

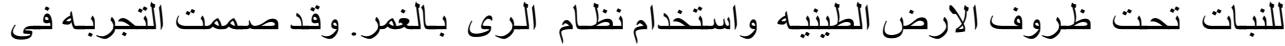

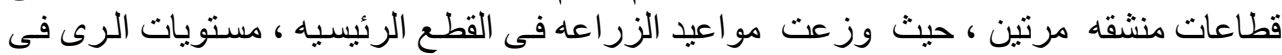

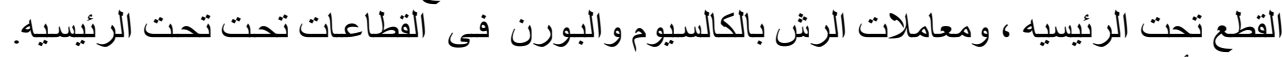

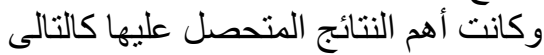

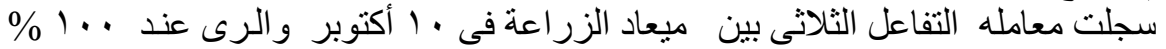

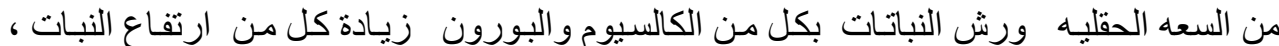

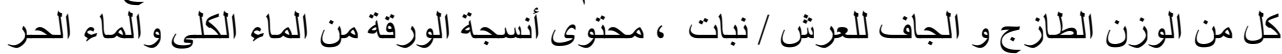

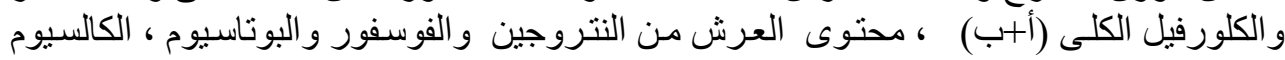

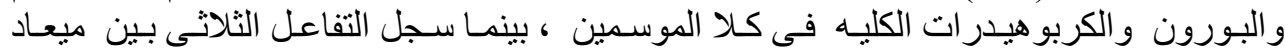

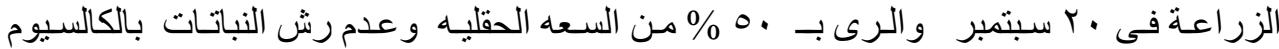

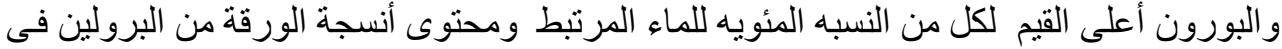

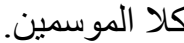

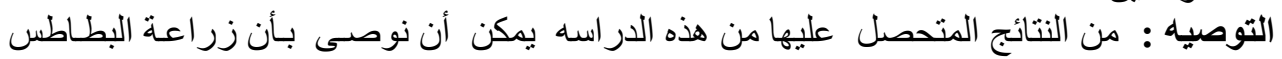

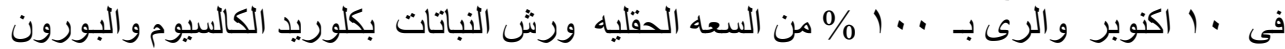

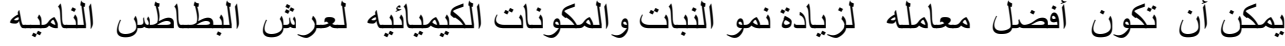

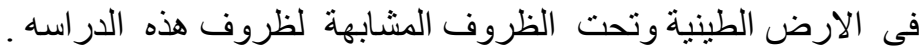

